\title{
TINJAUAN YURIDIS TENTANG TINDAK PIDANA PENGEROYOKAN YANG DI LAKUKAN OLEH ANAK DI BAWAH UMUR MENURUT UNDANG - UNDANG NOMOR 23 TAHUN 2002 TENTANG PERLINDUNGAN ANAK DAN UNDANG- UNDANG NOMOR 3 TAHUN 1997 TENTANG PERADILAN ANAK.
}

\author{
Dody Eko Wijayanto \\ Dosen Fakultas Hukum Universitas Islam Lamongan
}

\begin{abstract}
ABSTRAK
Anak adalah masa dimana banyak sekali terjadi hal-hal yang sangat kompleks yang salah satunya adalah perbuatan kenakalan yang menjurus kepada tindak pidana. Terminologi internasional yang digunakan untuk menyebut kenakalan anak yang melakukan pelanggaran hukum adalah "Anak yang Berhadapan dengan Hukum". Sejak disadari bahwa anak juga melakukan pelanggaran hukum, perdebatan tentang bagaimana cara yang terbaik untuk menghadapinya, terus menerus berlangsung. Intervensi terhadap anak yang berhadapan dengan hukum sangat luas dan beragam, tetapi kebanyakan lebih menekankan pada penahanan dan penghukuman, tanpa peduli betapa ringannya pelanggaran tersebut atau betapa mudanya usia anak tersebut. Tindak pidana pengeroyokan adalah suatu tindak pidana yang dimana dilakukan oleh lebih dari satu orang dengan unsur mengakibatkan rasa sakit pada tubuh, luka pada tubuh, dan merugikan kesehatan tubuh.Dalam sistematika hukum pidana di Indonesia suatu tindakan pengeroyokan sebagaimana telah di atur dalam Kitab Undang-Undang Hukum Pidana Pasal 170 KUHP.
\end{abstract}

\section{Kata Kunci : Pengeroyokan}

\section{PENDAHULUAN}

Pada dasarnya kehidupan manusia tidak dapat dipisahkan dari hukum. Sepanjang sejarah peradaban manusia, peran sentral hukum dalam upaya menciptakan suasana yang memungkinkan manusia merasa terlindungi, hidup berdampingan secara damai, dan menjaga eksistensinya di dunia telah diakui. ${ }^{11}$ Pengertian tersebut didasarkan pada penglihatan hukum dalam arti kata materiil, sedangkan dalam

11 Jhonny Ibrahim, Teori \& Metode Penelitian Hukum Normatif, Bayumedia Publishing, Malang, 2005, h. 1 arti kata formil, hukum adalah kehendak manusia ciptaan manusia berupa normanorma yang berisikan petunjuk tingkah laku tentang apa yang boleh dilakukan dan tentang apa yang tidak boleh dilakukan, yang dilarang dan dianjurkan untuk dilakukan. ${ }^{12}$

Unsur utama yang dibutuhkan manusia dari hukum adalah ketertiban. Dengan terwujudnya ketertiban, maka berbagai keperluan sosial manusia dalam bermasyarakat akan terpenuhi. Untuk

\footnotetext{
${ }^{12}$ Chainur Arrasjid,Dasar-dasar Ilmu Hukum,
} Penerbit Sinar Grafika, Jakarta, 2000, h. 21 
mewujudkan ketertiban itu manusia memunculkan keharusan-keharusan berperilaku dengan cara tertentu yang dirumuskan dalam bentuk kaidah.Ketertiban dan kaidah yang diperlukan manusia adalah ketertiban dan kaidah yang secara otentik menciptakan kondisi yang memungkinkan manusia secara wajar mewujudkan kepribadiannya secara utuh yang dengan itu ia dapat mengembangkan semua potensi kemanusiaan seperti apa yang secara bebas dikehendakinya. ${ }^{13}$

Unsur kedua yang tidak kalah pentingnya, yakni keadilan. Keadilan senantiasa mengandung unsur penghargaan, penilaian dan pertimbangan. Karena itu mekanisme bekerjanya hukum digambarkan sebagai suatu neraca keadilan. Keadilan menuntut bahwa dalam keadaan yang sama setiap orang harus menerima bagian yang sama pula. Sehubungan dengan keadilan tersebut hukum bersifat kompromistis, karena keadilan manusia tidaklah mutlak. Mengingat, manusia adalah makhluk tidak sempurna, kekhilafan merupakan sifat insani manusia. Aliran hukum alam meyakini bahwa keadilan itu hanya bersumber dari Tuhan Yang Maha Esa, tetapi manusia juga diberi kecakapan dan kemampuan untuk meraba atau merasakan apa yang dinamakan adil. Aliran hukum alam mempercayai bahwa apa yang diamati dalam segala kejadian alam sekitar manusia sudah menumbuhkan dasar-dasar keadilan. ${ }^{14}$

Fungsi hukum untuk memberikan perlindungan yaitu terhadap kepentingan manusia (seluruh manusia tanpa terkecuali). Oleh karena itu maka hukum harus dilaksanakan agar kepentingan manusia tersebut dapat terlindungi. Pada dasarnya suatu hukum yang baik adalah

${ }^{13}$ Jhonny Ibrahim, Op.Cit, h. 2

${ }^{14}$ Ibid, h. 5 hukum yang mampu menampung dan membagi keadilan pada orang-orang yang akan diaturnya. Hukum mempunyai fungsi untuk memberikan perlindungan terhadap kepentingan manusia (seluruh manusia tanpa terkecuali). Oleh karena itu hukum harus dilaksanakan agar kepentingan manusia tersebut dapat terlindungi. Dalam pelaksanaannya, hukum dapat berlangsung secara normal dan damai, akan tetapi dapat juga terjadi pelanggaran-pelanggaran hukum dalam prakteknya. Hukum yang dilanggar itu harus ditegakkan. Melalui penegakan hukum inilah hukum ini menjadi kenyataan.

Setiap orang mengharapkan dapat ditetapkannya hukum dalam hal terjadi peristiwa konkrit. Bagaimana hukumnya itulah yang harus berlaku (meskipun dunia ini runtuh hukum harus ditegakkan). Itulah yang diinginkan oleh kepastian hukum. Masyarakat mengharapkan adanya kepastian hukum. Karena dengan adanya kepastian hukum masyarakat akan lebih tertib. Sebaliknya masyarakat mengharapkan manfaat dalam pelaksanaan atau penegakan hukum. Masyarakat sangat berkepentingan bahwa dalam pelaksanaan atau penegakan hukum, keadilan diperhatikan.

Dalam kehidupan bermasyarakat diperlukan suatu sistem hukum untuk menciptakan kehidupan masyarakat yang harmonis dan teratur. Kenyataannya hukum atau peraturan perundangundangan yang dibuat tidak mencakup seluruh perkara yang timbul dalam masyarakat sehingga menyulitkan penegak hukum untuk menyelesaikan perkara tersebut.Di kota-kota indsutri dan kota besar yang cepat berkembang, kasus kejahatan yang terjadi jauh lebih banyak dari pada kota-kota kecil atau pedesaan. Kenyataan menunjukan bahwa bentuk dan jenis kejahatan anak atau remaja semakin bertambah jumlahnya dengan semakin 
berkembangannya industrialisasi, urbanisasi, dan ekonomi. ${ }^{15}$

Kemajuan tekhnologi, industry urbanisasi, ekonomi, banyak menyebabkan masalah social, sehingga sangat sulit menyesuaikan masalahmasalah yang sangat kompleks tersebut. Kesulitan mengadakan penyesuaian diri ini menimbulkan banyak kebimbangan, kebingungan, kecemasan, dan konflik. Hal ini dapat menimbulkan penyimpangan pola tingakah laku dari norma-norma umum yang dapat mengganggu dan merugikan orang lain.Penyimpangan tingkah laku atau perbuatan melanggar hukum yang berupa tindak pidana pada saat akhir-akhir ini tidak hanya dilakukan oleh orang dewasa melainkan dilakukan juga oleh anak-anak, adapun penyebabnya disebabkan oleh berbagai faktor, antara lain adanya dampak negatif perkembangan yang cepat, arus globalisasi di bidang komunikasi dan informasi, kemajuan ilmu pengetahuan dan teknologi serta perubahan gaya dan cara hidup sebagian orang tua, telah membawa perubahan sosial yang mendasar dalam kehidupan masyarakat yang sangat berpengaruh terhadap nilai dan perilaku anak. Intervensi terhadap anak yang berhadapan dengan hukum sangat luas dan beragam, tetapi kebanyakan lebih menekankan pada penahanan dan penghukuman, tanpa peduli betapa ringannya pelanggaran tersebut atau betapa mudanya usia anak tersebut.

Tingkah laku atau perbuatan melanggar hukum yang dilakukan oleh anak, disebabkan oleh berbagai faktor, antara lain adanya dampak negatif perkembangan yang cepat, arus globalisasi di bidang komunikasi dan informasi, kemajuan ilmu pengetahuan

${ }^{15}$ Sarlito Wirawan Sarwono, Psikologis Remaja, edisi revisi, Cet 6, (Jakarta: PT. Raja Grafindo Persada, 2002), Bab III-IV dan teknologi serta perubahan gaya dan cara hidup sebagian orang tua, telah membawa perubahan sosial yang mendasar dalam kehidupan masyarakat yang sangat berpengaruh terhadap nilai dan perilaku anak.Anak sebagai bagian dari masyarakat atau subyek hukum yang tidak lepas dari suatu permasalahan ini, bahkan sangat cenderung terlibat dalam penyimpangan pola tingkah laku ini karena mereka masih dalam tahap perkembangan baik fisik maupun psikis. ${ }^{16}$

Kaum remaja atau transisi adalah individu yang berada di antara masa kanak-kanak dan kehidupan dewasa,pada waktu transisi tersebut,para remaja atau anak mulai berminat terhadap diri sendiri dan kesadaran tentang dirinya sebagai individu berkepribadian.Konflik / pertentangan dalam gangguan emosional yang di alami oleh anak atau remaja ini merupakan dasar untuk melakukan tindakan melawan hukum dengan menunjukkan akan kemampuannya untuk mendapatkan jati dirinya dengan unsur melawan hukum yang dimana atas perbuatannya dapat merugikan orang lain atau bahkan dapat mengambil kemerdekaan seseorang.Terminologi internasional yang digunakan untuk menyebut kenakalan anak yang melakukan pelanggaran hukum adalah "Anak yang Berhadapan dengan Hukum". Sejak disadari bahwa anak juga melakukan pelanggaran hukum, perdebatan tentang bagaimana cara yang terbaik untuk menghadapinya, terus menerus berlangsung. Intervensi terhadap anak yang berhadapan dengan hukum sangat luas dan beragam, tetapi kebanyakan lebih menekankan pada penahanan dan penghukuman, tanpa peduli betapa ringannya pelanggaran tersebut atau betapa mudanya usia anak tersebut. 
Anak yang dimana telah di atur dalam Undang-Undang Nomor 23 Tahun 2002 yang dimana sebagai landasan hukum bagi perlindungan anak di Indonesia, dan Keberadaan UndangUndang Nomor 3 Tahun 1997 tentang Pengadilan Anak memang sangat dibutuhkan di dalam menangani anakanak yang melakukan tindak pidana, pada hakekatnya anak adalah sebagai penerus bangsa akan perjuangan bangsa. Akan tetapi perlindungan ini tidak hanya berlaku bagi anak yang berprilaku baik saja, tetapi juga bagi anak-anak yang melakukan tindak pidana termasuk pada anak yang dijatuhi sanksi penjara atas perbuatan yang dilakukan adalah pengeroyokan yang dimana lebih dari seorang atau lebih dari satu pelaku tindak pidana. Individu atau kelompok yang menyerang satu sama lain termasuk sebagai perilaku agresif.

Tindak pidana pengeroyokan ini yang dimana telah dikutip dalam Kitab Undang-Undang Hukum Pidana (KUHP) Pasal 170 dirumuskan sebagai barangsiapa dengan terang-terangan dan dengan tenaga bersama menggunakan kekerasan terhadap orang lain atau barang, diancam dengan pidana penjara paling lama lima tahun enam bulan. ${ }^{17}$ Pembedaan perlakuan dan ancaman yang diatur dalam UndangUndang dimaksudkan untuk melindungi dan mengayomi anak tersebut agar dapat menyongsong masa depan yang panjang. Sebagaimana disebutkan dalam Undangundang Perlindungan Anak adalah segala kegiatan untuk menjamin dan melindungi anak dan hak-haknya agar dapat hidup, tumbuh, berkembang dan berpartisipasi, secara optimal sesuai dengan harkat dan martabat kemanusiaan, serta mendapat perlindungan dari kekerasan dan diskriminasi.
Sedangkan dalam pasal 1 butir ke 15 dalam Undang-undang Perlindungan anak juga menyebutkan tentang perlindungan khusus bagi anak adalah perlindungan yang diberikan kepada anak dalam situasi darurat, anak berhadapan dengan hukum.Selain itu pembedaan tersebut dimaksudkan untuk memberi kesempatan kepada anak melalui pembinaan akan diperoleh jati dirinya untuk menjadi manusia yang mandiri, bertanggung jawab,dan berguna bagi diri, keluarga, masyarakat, bangsa dan negara. ${ }^{18}$

Sebagaimana telah di kutip dalam Kitab Undang-Undang Hukum Pidana bahwa sebagaimana bagi pelaku tindak Pidana yang terbukti melawan Hukum di kenakan Pemidanaan Penjara untuk Penjerahan atas perbuatan yang telah dilakukannya. Atas pengaruh dari keadaan sekitarnya maka tidak jarang anak ikut melakukan tindak pidana.

Hal itu dapat disebabkan oleh bujukan, spontanitas atau sekedar ikutikutan.Meskipun demikan tetap saja hal itu merupakan tindakan pidana. Namun demi pertumbuhan dan perkembangan mental anak, perlu diperhatikan pembedaan perlakuan di dalam hukum acara dan ancaman pidana. Menurut pasal 45 Kitab Undang-Undang Hukum Pidana (selanjutnya disingkat dengan KUHP) bahwa anak yang belum dewasa apabila belum berumur 16 tahun. Apabila anak terlibat dalam perkara pidana hakim boleh memerintahkan agar tersangka di bawah umur tersebut dikembalikan kepada orang tuanya, walinya, dan pemeliharaanya dengan tidak dikenakan suatu hukuman atau memerintahkan supaya diserahkan kepada pemerintah dengan tidak dikenakan suatu hukuman. 
untuk $\begin{gathered}\text { Pemidanaan tidak dimaksudkan } \\ \text { menderitakan dan tidak }\end{gathered}$ diperkenankan merendahkan martabat manusia, merupakan pemberian makna kepada pidana dalam sistem hukum Indonesia. Ketentuan ini akan berpengaruh terhadap pelaksanaan pidana yang secara nyata akan dikenakan kepada terpidana. Tujuan pemidanaan bukan merupakan pembalasan kepada pelaku dimana sanksi ditekankan pada tujuannya, yakni untuk mencegah agar orang tidak melakukan kejahatan.Sanksi pidana yang dijatuhkan kepada anak didasarkan pada kebenaran, keadilan, dan kesejahteraan anak. Penjatuhan pidana atau tindakan merupakan suatu tindakan yang harus mempertanggungjawabkan dan bermanfaat bagi anak. Hakim wajib mempertimbangkan keadaan anak, keadaan rumah, keadaan lingkungan dan laporan pembimbing kemasyarakatan. Pasal 23 Undang-Undang No 3 Tahun 1997 tentang Pengadilan Anak yang menentukan :

1) Pidana yang dapat dijatuhkan kepada Anak Nakal yaitu :

Pidana Pokok dan Pidana Tambahan.

2) Pidana Pokok yang dapat dijatuhkan kepada Anak Nakal ialah :
a) Pidana Penjara;
b) Pidana Kurungan;
c) Pidana Denda atau;
d) Pidana Pengawasan

3) Selain pidana pokok sebagiamana dimaksud dalam ayat (2) terhadap Anak Nakal dapat juga dijatuhkan pidana tambahan ialah:

a) Perampasan barang-barang tertentu

b) Pembayaran ganti rugi.

Terdorong oleh kenyataan tersebut, penulis merasa tertarik untuk mencoba menguraikan masalah tindak pidana pengeroyokan yang dilakukan oleh anak khususnya mengenai analisis yuridis tindak pidana pengeroyokan yang kemudian penulis menyusun ke dalam skripsi dengan judul Tinjauan Yuridis Tentang Tindak Pidana Pengeroyokan Yang Di Lakukan Oleh Anak Di Bawah Umur Menurut Undang - Undang Nomor 23 Tahun 2002 Tentang Perlindungan Anak Dan Undang-Undang Nomor 3 Tahun 1997 Tentang Peradilan Anak.

\subsection{Perumusan Masalah}

Berdasarkan latar belakang masalah diatas maka dapat dirumuskan permasalahan sebagai berikut :

1. Bagaimanakah ketentuan hukum mengenai tindak pidana pengeroyokan yang dilakukan oleh anak dibawah umur menurut kitab undang-undang hukum pidana?

2. Bagaimana akibat hukum terhadap tindak pidana pengeroyokan yang dilakukan oleh anak dibawah umur menurut Undang-Undang Perlindungan Anak nomor 23 tahun 2002 dan Undang-Undang Nomor 3 tahun 1997 tentang Peradilan Anak?

\subsection{Tujuan Penelitian}

Dalam penelitian ini ada dua tujuan yang ingin diketahui antara :

1. Untuk mengetahui ketentuan hukum mengenai tindak pidana pengeroyokan yang dilakukan oleh anak dibawah umur menurut Kitab Undang-Undang Hukum Pidana.

2. Untuk mengetahui akibat hukum terhadap tindak pidana pengeroyokan yang dilakukan oleh anak dibawah umur menurut Undang-Undang Nomor 23 Tahun 2002 tentang Perlindungan Anak dan UndangUndang Nomor 3 tahun 1997 tentang Peradilan Anak.

\subsection{Manfaat Penelitian}

penulis dari penelitian ini antara lain :

Dengan hasil penelitian terhadap tindak pidana pengeroyokan yang dilakukan oleh anak dibawah umur diharapkan dapat memberikan manfaat atau kegunaan baik bersifat teoristis maupun praktis adalah sebagai berikut:

1. Kegunaan teoristis

Diharapkan dengan hasil penelitian ini akan memberi 
pengetahuan hukum di Indonesia yang mengupas masalah tindak pidana pengeroyokan yang dilakukan oleh anak di bawah umur.

2. Kegunaan Praktis

Diharapkan dengan hasil penelitian akan memberikan masukan berupa pemecahan berkaitan dengan tindak pidana pengeroyokan yang dilakukan oleh anak di bawah umur, disamping itu penelitian ini dapat dapat memberikan informasi kepada masyarakat pada khususnya anak sehingga tidak melakukan tindak pidana ini.

\section{METODE PENELITIAN}

Tipe Penelitian hukum yang di lakukan adalah penelitian Yuridis normatife (hukum normatif). Metode Penelitian Hukum normatif adalah suatu prosedur penelitian ilmiah untuk menemukan kebenaran berdasarkan logika keilmuan hukum dari sisi normatifnya. ${ }^{19}$ Oleh karena tipe penelitian yang di gunakan adalah tipe penelitian yuridis normatif, maka pendekatan yang digunakan adalah pendekatan perundangundangan (statute approach) dan pendekatan konsep (conseptual). Pendekatan konsep ini di gunakan dalam rangka untuk melihat konsep - konsep mengenaiTinjauan Yuridis Tentang Tindak Pidana Pengeroyokan Yang Di Lakukan Oleh Anak Di Bawah Umur Menurut Undang - Undang Nomor 23 Tahun 2002 Tentang Perlindungan Anak Dan Undang-Undang Nomor 3 Tahun 1997 Tentang Peradilan Anak. Jika demikian, pendekatan peraturan perundang-undangan adalah pendekatan dengan menggunakan legislasi dan regulasi. ${ }^{20}$

\footnotetext{
${ }^{19}$ Jhonny ibrahim, Teori \& Metode Penelitian Hukum Normatif, Banyumedia Publishing, Malang 2006.h .57.

${ }^{20}$ Peter Mahmud Marzuki, Penelitian Hukum, Kencana Prenada Media Group, Jakarta, 2010, h, 96.

Bahan hukum yang di pergunakan dalam penelitian ini adalah sebagai berikut: Bahan hukum primer yakni bahan hukum terdiri dari perundang-undangan, catatan resmi, atau risalah dalam pembuatan perundang-undangan dan putusan hakim. Bahan sekunder adalah bahan hukum yang diperoleh dari buku teks,jurnal-jurnal asing, pendapat para sarjana dan kasus-kasus hukum,serta symposium yang dilakukan para pakar. Bahan Hukum tersier adalah bahan hukum seperti kamus hukum, ensiklopedia dan lain-lain. Maka dalam pengumpulan bahan hukum penulis mengunakan studi dokumen atau bahan pustaka dalam penulisan skripsi ini.

\section{HASIL DAN PEMBAHASAN}

Pengeroyokan adalah proses, cara, perbuatan mengeroyok memiliki pengertian bahwa tindak pelanggaran hukum yang bersama-sama melakukan kekerasan terhadap orang atau barang atau yang biasa. Perbuatan ini melanggar perundang-undangan yang termuat dalam pasal 170 Kitab Undang-Undang Hukum Pidana (KUHP) yang berisi ${ }^{21}$ :

(1) Barang siapa yang di muka umum bersama-sama melakukan kekerasan terhadap orang atau barang, dihukum penjara selama-lamanya lima tahun enam bulan.

(2) Tersangka dihukum:

1. Dengan penjara selama-lamanya tujuh tahun, jika ia dengan sengaja merusakkan barang atau kekerasan yang dilakukannya itu menyebabkan sesuatu luka.

2. Dengan penjara selama-lamanya sembilan tahun, jika kekerasan itu menyebabkan luka berat pada tubuh.

3. Dengan penjara selama-lamanya dua belas tahun, jika kekerasan itu menyebabkan matinya orang.

(3) Pasal 89 KUHP tidak berlaku Perlu diuraikan unsur-unsur yang terdapat dalam pasal ini sebagai berikut: 
1) Barang siapa. Hal ini menunjukan kepada orang atau pribadi sebagai pelaku.

2) Di muka umum. Perbuatan itu dilakukan di tempat dimana publik dapat melihatnya.

3) Bersama-sama, artinya dilakukan oleh sedikit-dikitnya dua orang atau lebih. Arti kata bersama-sama ini menunjukan bahwa perbuatan itu dengan sengaja (delik dolus) atau memiliki tujuan yang pasti, jadi bukanlah merupakan ketidak sengajaan (delik culpa).

4) Kekerasan, yang berarti mempergunakan tenaga atau kekuatan yang tidak kecil dan tidak sah. Kekerasan dalam pasal ini biasanya terdiri dari "merusak barang" atau "penganiyaan"

5) Terhadap orang atau barang. Kekerasan ini harus ditujukan kepada orang atau barang sebagai korban

Terhadap orang atau barang. Kekerasan ini harus ditujukan kepada orang atau barang sebagai korban. Jadi beberapa pengertian dan penjelasan tersebut dapat disimpulkan bahwa untuk menyebut seseorang itu telah melakukan penganiayaan bersama-sama atau dengan kata lain melakukan tindakan pengeroyokan terhadap orang lain, maka orang tersebut harus mempunyai kesengajaan untuk :

a. Menimbulkan rasa sakit pada orang lain.

b. Menimbulkan luka pada tubuh orang lain.

c. Merugikan kesehatan orang lain.

Secara bersama-sama artinya dilakukan dua orang atau lebih dan dilakukan dimuka umum. Tindakan kekerasan ini merupakan tindakan yang mengganggu ketertiban umum dan jelas merupakan kejahatan. Sedangkan jika orang hanya mengikuti dan tidak ikut serta melakukan kekerasan, tidak berlaku untuk pasal tersebut. Misalnya perkelahian dua kelompok remaja atau anak-anak.Pengertian bersama-sama disini, bahwa perbuatan tersebut dilakukan bersama-sama tanpa ada tenggang waktu yang lama. Jadi mereka dengan serentak melakukan tindakan kekerasan. Tahap suatu tindak pidana terhadap orang yang dilakukan bersamasama dibedakan atas tindak pidana yang menimbulkan luka ringan, menimbulkan luka berat, dan bahkan menimbulkan kematian.Mencermati pasal 170 KUHP terdapat uraian-uraian tentang tindak pidana dan pidana yang dikenakan pada pelaku pidana tersebut yang berbunyi “ dengan pidana penjara selama-lamanya dua belas tahun kalau kekerasaan itu menyebabkan matinya orang".

Secara umum tindak pidana terhadap tubuh pada KUHP disebut Penganiayaan. (W.J.S Poerwadaminta 1994:48) dikatakan bahwa penganiayaan adalah perlakuan sewenang-wenang (penyiksaan, penindasan, dan sebagainya). Sedangkan dalam KUHP sendiri tidak memberikan penjelasan tentang apa yang dimaksud dengan istilah penganiayaan.Dengan kata lain untuk menyebut seseorang dengan melakukan pengeroyokan, maka orang itu harus mempunyai kesengajaan alam melakukan suatu perbuatan untuk membuat rasa sakit pada orang lain atau luka pada tubuh orang lain atau orang itu dalam perbuatannya merugikan kesehatan orang lain.

Perbuatan pidana adalah perbuatan yang dilarang oleh suatu aturan hukum larangan di sertai ancaman (sanksi) yang berupa pidana tertentu bagi barang siapa melanggar larangan tersebut. Dapat juga dikatakan bahwa perbuatan pidana adalah perbuatan yang oleh suatu aturan hukum di larang dan diancam pidana, asal saja perlu di ingat bahwa larangan ditujukan kepada perbuatan (yaitu suatu keadaan atau kejadian yang 
ditimbulkan oleh kelakuan orang), sedangkan ancaman pidananya ditujukan kepada orang yang menimbulkan kejadian itu.Antara larangan dan ancaman pidana ada hubungan yang erat, karena antara kejadian dan orang yang menimbulkan kejadian itu, ada hubungan erat pula. Yang satu tidak dapat dipisahkan dari yang lain.

Kejadian tidak dapat di larang jika menimbulkan bukan orang, dan orang tidak dapat diancam pidana, jika tidak karena kejadian yang ditimbulkan olehnya. Justru untuk menyatakan hubungan yang erat itu maka dipakailah perkataan perbuatan, yaitu suatu pengertian abstrak yang menunjukan kepada dua keadaan kongkrit : pertama, adanya kejadian tertentu dan kedua, adanya orang yang berbuat yang menimbulkan kejadian itu.Atas dasar uraian objek tindak pidana diatas penulis sependapat dengan perumusan-perumusan dalam KUHP tersebut yang menyatakan bahwa objek pidana adalah orang atau oknum. Banyak fenomena terjadi, peristiwa-peristiwa alam yang menyebabkan luka atau matinya orang. Di sini tidak ada subjek pidana dalam hal ini penulis sependapat bahwa hal tersebut tidak termasuk tindak pidana karena tidak ada orang atau oknum yang menjadi penyebab luka atau kematian.Unsur penting dalam pidanayakni : Pertama, subjek tindak pidana sebagai pelaku atau melakukan hingga terjadi suatu peristiwa atau tindakan, misalnya penganiayan dan perusakan. Unsur yang kedua, perbuatan tindak pidana. Perbuatan tindak pidana memiliki latar belakang yang berbedabeda. Bisa dipicu oleh ketidakpuasan tindakan kelompok tertentu atau faktor lain seperti yang tersebut di atas. Unsur yang ketiga, hubungan sebab akibat (causal verband). " Bahwa ada tindak pidana sebagai unsur pokok harus ada akibat tertentu dari perbuatan si pelaku yang berupa kerugian atas kepentingan orang lain, menandakan ada hubungan sebab akibat. 1. Akibat Hukum Tindak Pidana Pengeroyokan Menurut Hukum Pidana Indonesia.Dalam hukun pidana Indonesia menerangkan bahwa suatu akibat pidana pengeroyokan telah di atur pada pasal 170 KUHP (Kitab UndangUndang Hukum Pidana): “ Barang siapa yang di muka umum bersama-sama melakukan kekerasan terhadap orang atau barang di hukuim penjara selama lima tahun enam bulan".

Anak adalah amanah sekaligus karunia Tuhan Yang Maha Esa, yang senantiasa harus kita jaga karena dalam dirinya melekat harkat, martabat, dan hakhak sebagai manusia yang harus dijunjung tinggi. Hak asasi anak merupakan bagian dari hak asasi manusia yang termuat dalam Undang-Undang Dasar 1945 dan Konvensi Persirakatan Bangsa-Bangsa tentang Hak-Hak Anak. Dari sisi kehidupan berbangsa dan bernegara, anak adalah masa depan bangsa dan generasi penerus cita-cita bangsa, sehingga setiap anak berhak atas kelangsungan hidup, tumbuh, dan berkmbang, berpartisipasi serta berhak atas perlindungan dari tindak kekerasan dan diskriminasi serta hak sipil dan kebebasan.

Meskipun Undang-Undang Nomor 39 Tahun 1999 tentang Hak Asasi Manusia telah mencantumkan tentang hak anak, pelaksanaan kewajiban dan tanggung jawab orang tua, keluarga, masyarakat, pemerintah, dan Negara untuk memberikan perlindungan kepada anak masih memerlukan suatu undangundang mengenai perlindungan anak sebagai landasan yuridis bagi pelaksanaa kewajiban dan tanggung jawab tersebut. Dengan demikian, pembentukan UndangUndang ini didasarkan pada pertimbangan bahwa perlindungan anak dalam segala aspeknya merupakan bagian dari kegiatan pembangunan nasional, khususnya dalam 
memajukan kehidupan berbangsa dan bernegara.

Undang-Undang ini menegaskan bahwa pertanggung jawaban orang tua, keluarga, masyarakat, pemerintah, dan Negara merupakan rangkain kegiatan yang dilaksakan secara terus menerus demi terlindunginya hak-hak anak. Rngkaian kegiatan tersebut harus berkelanjutkan dan terarah guna menjamin pertumbuhan dan perkembangan anak, baik fisik mental, spiritual maupun social.. Upaya perlindungan anak perlu dilaksanakan sedini mungkin yakni sejak dari janin dalam kandungan sampai anak umur 18 Tahun. Dalam melakukan pembinaan, pengembangan dan perlindungan anak, perlu peran masyarakat, baik melalui lembaga perlindungan anak, lembaga keagamaan, lembaga swadaya masyarakat, organisasi kemasyarakatan,organisasi sosila, dunia usaha, media massa, atau lembaga pendidikan.

1. Dalam tindak pidana pengeroyokan yang di lakukan oleh anak dibawah umur diatur menurut undangundang nomor 23 Tahun 2002 tentang perlindungan anak. Yang dimaksud sebagai berikut :

a. Anak adalah seseorang yang belum berusia delapan belas tahun termasuk anak yang masih dalam kandungan.

b. Perlindungan anak adalah segala kegiatan untuk menjamin dan melindungi anak dan hakhaknya agar dapat hidup, tumbuh, berkembang, dan berpartisipasi, secara optimal sesuai dengan harkat dan martabat kemanusiaan, serta mendapat perlindungan dari kekerasan dan diskriminasi.

Akibat Hukum Pengeroyokan anak dibawah umur menurut Undang-undang nomor 23 tahun 2002 tentang perlindungan anak:

i. Bagian Kelima Perlindungan Khusus menurut Pasal 64 :

Ayat (1). Perlindungan khusus bagi anak yang berhadapan dengan hukum yang sebagaimana dimaksud dalam pasal 59 meliputi anak yang berkonflik dengan hukum dan anak korban tindak pidana, merupakan kewajiban dan tanggung jawab pemerintah dan masyarakat.

Ayat (2). Perlindungan khusus bagi anak yang berhadapan dengan hukum sebagaimana dimaksud dalam ayat (1) dilaksanakan melalui:

a. Perlakuan anak secara manusiawi sesuai dengan martabat dan hak-hak anak.

b. Penyediaan petugas pendamping khusus anak sejak dini.

c. Penyediaan sarana dan prasarana khusus.

d. Penjatuhan sanksi yang tepat untuk kepentingan yang terbaik bagi anak.

e. Pemantauan dan pencatatan terus menerus terhadap perkembangan anak yang berhadapan dengan hukum.

f. Pemberian jaminan untuk mempertahankan hubungan dengan orang tua atau keluarga.

g. Perlindungan dari pemberitaan identitas melalui media massa dan untuk menghindari labelisasi.

Ayat (3) . Perlindungan khusus bagi anak yang menjadi korban pidana sebagaimana yang dimaksud dalam ayat

(1) dilakasanakan melalui:

a. Upaya rehabilitasi, baik dalam lembaga maupun diluar lembaga.

b. Upaya perlindungan dari pemberitaan identitas melalui media massa dan untuk menghindari labelisasi.

c. Pemberian jaminan keselamatan bagi korban dan saksi ahli, baik fisik mental maupun social.,dan

d. Pemberian aksesibilitas untuk mendapatkan informasi mengenai perkembangan perkara.

Pasal 65Ayat (1). 
Perlindungan khusus bagi anak dari kelompok minoritas dan terisolasi sebagaimana dimaksud dalam pasal 59 dilakukan melalui penyediaan prasaran dan sarana untuk dapat menikmati budaya sendiri mengakui dan melaksanakan ajaran agamanya sendiri dan menggunakan bahasanya sendiri.

Ayat (2).

Setiap orang dilarang menghalanghalangai anak sebagaimana dimaksud dalam ayat 1 . untuk menikmati budayanya sendiri,mengakui dan melaksanakan ajaran agamanya, dan melaksanakan agamanya sendiri tanpa mengabaikan akses pembangunan masyarakat dan budaya.

a. Pemanatauan, pelaporan, dan pemberian sanksi dan

b. Perlibatan berbagai intansi pemerintah, perusahaan, serikat pekerja, lembaga swadaya masyarakat, dan masyarakat dalam penghapusan eksploitasi terhadap anak secara ekonomi dan atau seksual. Ayat (3). Setiap orang dilarang menempatkan, membiarkan, melakukan, menyuruh melakukan, atau turut serta melakukan eksploitasi terhadap anak sebagimana dimaksud dalam ayat 1 .

Pasal 69Ayat (1).

Perlindunga khusus bagi anak korban kekerasan sebagaimana dimaksud dalam pasal 59 meliputi kekerasan fisik, psikis, dan seksual dilakukan melalui upaya:

ii. Penyebar luasana dan sosialisasi dan ketentuan perundang-undangan yang melindungi anak korban tindak kekerasan., dan

iii. Pemantauan, pelaporan, dan pemberian saksi.

Ayat (2). Setiap orang dilarang menempatkan, memebiarkan, melakukan, menyuruh melakukan atau turut serta melakukan kekerasan sebagaimana dimaksud dalam ayat 1.Pengadilan anak menurut Undang-Undang Nomor 3 Tahun 1997 tentang Pengadilan Anak merupakan pengkhususan dari sebuah badan peradilan, yaitu peradilan umum untuk menyelenggarakan pengadilan anak. Akibatnya dalam pengadilan tidak mencerminkan peradilan yang lengkap bagi anak, melainkan hanya mengadili perkara pidana anak.

Tujuan dari sistem peradilan pidana yakni resosialiasi serta rehabilitasi anak (reintegrasi) dan kesejahteraan sosial anak tidak melalui keadilan restoratif dan diversi tidak menjadi substansi undangundang tersebut. Akibatnya perkara anak, meskipun hanya melakukan tindak pidana ringan harus menghadapi negara melalui aparat penegak hokum. Keberadaan Undang-Undang Nomor 3 Tahun 1997 tentang Pengadilan Anak apabila dikaji secara substantif, belum sepenuhnya dapat dikategorikan sebagai hukum pidana anak materiil pada satu pihak dan sebagai hukum acara pidana anak pada lain pihak. Hal ini dapat dilihat dari hubungan antara Undang-Undang ini dengan Kitab Undang-Undang Hukum Pidana (KUHP) dan Kitab Undang-Undang Hukum Acara Pidana (KUHAP) merupakan hubungan hukum khusus dan hukum umum, Undang-Undang Nomor 3 Tahun 1997 tentang Pengadilan Anak merupakan hukum khusus (lex specialis) dan Kitab Undang-Undang Hukum Pidana (KUHP) dan Kitab Undang-Undang Hukum Acara Pidana (KUHAP) merupakan hukum umum (lex generalis). Hubungan ini mengandung arti bahwa asas-asas dan ajaran-ajaran hukum pidana yang terkandung dalam KUHP dan KUHAP pun tetap berlaku untuk pengadilan anak.

\section{KESIMPULAN}

Bahwa pada dasarnya suatu tindak pidana pengeroyokan adalah suatu tindak pidana yang dimana dilakukan oleh lebih dari satu orang dengan unsur mengakibatkan rasa sakit pada tubuh, luka pada tubuh, dan merugikan kesehatan 
tubuh. Dalam sistematika hukum pidana di Indonesia suatu tindakan pengeroyokan sebagaimana telah di atur dalam Kitab Undang-Undang Hukum Pidana Pasal 170 KUHP menyimpulkan bahwa "Barang siapa yang dimuka umum bersama-sama melakukan kekerasan terhadap orang atau barang dihukum penjara selama lima tahun, enam bulan"Sedangkan didalam Undang-Undang Republik Indonesia Nomor 23 Tahun 2002 Tentang Perlindungan Anak yang berbunyi : "Anak adalah seseorang yang belum berusia 18 (delapan belas) tahun, termasuk anak yang masih dalam kandungan. Menurut pasal 64 Ayat (2), perlindungan khusus bagi anak yang berhadapan dengan hukum sebagaimana dimaksud dalam ayat (1) dilaksanakan melalui :

a. Perlakuan anak secara manusiawi sesuai dengan martabat dan hak-hak anak.

b. Penyediaan petugas pendamping khusus anak sejak dini.

c. Penyediaan sarana dan prasarana khusus.

d. Penjatuhan sanksi yang tepat untuk kepentingan yang terbaik bagi anak.

e. Pemantauan dan pencatatan terus menerus terhadap perkembangan anak yang berhadapan dengan hukum.

f. Pemberian jaminan untuk mempertahankan hubungan dengan orang tua atau keluarga.

g. Perlindungan dari pemberitaan identitas melalui media massa dan untuk menghindari labelisasi.

Upaya perlindungan anak perlu dilaksanakan sedini mungkin yakni sejak dari janin dalam kandungan sampai anak umur 18 Tahun. Bertitik tolak dari konsepsi perlindungan anak.

\section{DAFTAR PUSTAKA}

Chainur Arrasjid,Dasar-dasar Ilmu

Hukum, Penerbit Sinar Grafika, Jakarta, 2000, h. 21

Hasan Shadaly, Sosiologi Untuk Masyarakat Indonesia , ( Jakarta: Pustaka Sarjana, 1963), hlm.287

Jhony ibrahim, Teori \& Metode Penelitian Hukum Normatif,

Banyumedia Publishing, Malang, Tahun 2006.

Moeljatno, Azas-azas Hukum Pidana, Fakultas Hukum Uiversitas Gadjah Mada, Yogyakarta, 1980, h. 37

Peter Mahmud Marzuki, Penelitian Hukum, Kencana Prenadia Group, Jakarta, Tahun 2010.

Paul A, Samuelson, Economics Pengantar Uraian,(Jakarta : Viva Story Club 1987), hal 6.

R.soesilo, politeia-Bogor,1995 h.146

Sarlito Wirawan Sarwono, Psikologis Remaja, edisi revisi, Cet 6, (Jakarta: PT. Raja Grafindo Persada, 2002), Bab III-IV.

W.A. Bonger, Pengantar Kriminal, Cet.IV, ( Jakarta: Pembangunan dan Ghalia Indonesia, 1982 ), hlm 23.

\section{Peraturan Perundang-Undangan :}

Undang-undang Dasar Negara Republik Indonesia Tahun 1945

Kitab Undang-undang Hukum Pidana (KUHP),

Undang-Undang Nomor 3 Tahun 1997 tentang Pengadilan Anak

Undang-Undang Nomor 23 Tahun 2002 tentang Perlindungan Anak.

Undang-undang Nomor 11 Tahun 2012 Tentang Sistem Peradilan Anak

Internet :

http://id.shvoong.com/socialsciences/sociology/2170479pengertian-anak/ 